\title{
Preparation and properties of $\mathrm{SiC}$ honeycomb ceramics by pressureless sintering technology
}

\author{
Xingzhong GUO, Xiaobo CAI, Lin ZHU, Lingjie ZHANG, Hui YANG ${ }^{*}$ \\ Department of Materials Science and Engineering, Zhejiang University, Hangzhou 310027, China
}

Received: January 07, 2014; Revised: February 07, 2014; Accepted: February 12, 2014

(OThe Author(s) 2014. This article is published with open access at Springerlink.com

\begin{abstract}
SiC}$ honeycomb ceramics with parallel channels and macroporous walls were prepared by combining extrusion molding with pressureless sintering technology in the presence of starch. The extrusion molding constructed honeycomb structure with parallel channels, while the starch formed spherical macropores on the channel walls. The density and bending strength of SiC honeycomb ceramics decreased with the increase of starch content, while the phase compositions did not vary with the starch content. The control in starch addition could adjust the pore structures on the channel walls of $\mathrm{SiC}$ honeycomb ceramics.
\end{abstract}

Keywords: honeycomb ceramic; porous ceramic; silicon carbide ( $\mathrm{SiC})$; pore formation

\section{Introduction}

$\mathrm{SiC}$ honeycomb ceramics have attracted considerable attentions owing to its high wear resistance, high corrosion resistance, high coefficient of thermal conductivity, and thermal stability [1-9]. At present, $\mathrm{SiC}$ honeycomb ceramics are truly prepared by combining extrusion molding with recrystallization method [1], although some pore-creation processes such as polymeric precursor, and foam template have been developed to prepare $\mathrm{SiC}$ porous ceramics. The so-called recrystallized $\mathrm{SiC}$ ( $\mathrm{RSiC}$ ) honeycomb is a pure porous $\mathrm{SiC}$ material that is produced by heating up shapes consisting of a mixture of bimodal $\mathrm{SiC}$ powders at temperatures exceeding $2300{ }^{\circ} \mathrm{C}$ in a protecting gas atmosphere (Ar). However, the application of RSiC honeycomb is limited by its low mechanical properties (compression strength: 2.5$5 \mathrm{MPa}[2])$ and high recrystallization temperature. In

* Corresponding author.

E-mail: yanghui@zju.edu.cn particular, it is difficult to control the size and distribution of pores in the $\mathrm{RSiC}$ honeycomb walls. In our previous research, we have reported the preparation and pore structures of $\mathrm{SiC}$ honeycomb ceramics with macroporous walls by using iron oxide as pore former [10].

In this paper, we demonstrate the novel and facile method of preparing $\mathrm{SiC}$ honeycomb ceramics by combining extrusion molding with pressureless sintering technology in the presence of starch. The honeycomb structure with 70 cells per square inch and a wall thickness of about $400 \mu \mathrm{m}$ was obtained by extrusion molding technology, and spherical macropores with a size of $10-30 \mu \mathrm{m}$ distribute on the channel walls by means of pore-formation of the starch. A lot of benefits are expected to arise from the macroporous structure integrated in the honeycomb ceramics.

\section{Experiment}

The raw materials of $\mathrm{SiC}$ honeycomb ceramics 
included $\mathrm{SiC}$ composite powders, starch and additive agents. The $\mathrm{SiC}$ composite powders (Taizhou Dongxin Seal Co. Ltd., China) consisted of $90 \mathrm{wt} \% \mathrm{SiC}$ powders and $10 \mathrm{wt} \% \mathrm{~B}_{4} \mathrm{C}$ (boron carbide, as sintering agent). The starch (Sinopharm Chemical Reagent Co. Ltd., Shanghai, China) was used as pore-forming agent, and the adding content was designed to be $12.5 \mathrm{wt} \%, \quad 15 \mathrm{wt} \%, \quad 17.5 \mathrm{wt} \%$ and $20 \mathrm{wt} \%$. The additive agents such as hydroxypropyl methyl cellulose (HPMC, Sigma-Aldrich Co., USA), polyvinyl alcohol (PVA, Sigma-Aldrich Co., USA), oleic acid (Sinopharm Chemical Reagent Co. Ltd., Shanghai, China), glycerol (Sinopharm Chemical Reagent Co. Ltd., Shanghai, China), and poly(oxyethylene) (PEG 3000, Sigma-Aldrich Co., USA) were used to achieve extrusion molding.

All of the raw materials were mixed by ball milling for $0.5 \mathrm{~h}$, and kneaded by vacuum kneading machine for 3-4 times. The kneaded materials were trapped for $24 \mathrm{~h}$ and extrusion-molded to obtain the green bodies with honeycomb structure and parallel channels. After dried at $120{ }^{\circ} \mathrm{C}$ for $24 \mathrm{~h}$, the honeycomb green bodies were pressureless sintered at $2160{ }^{\circ} \mathrm{C}$ for $1 \mathrm{~h}$ in $\mathrm{Ar}$ atmosphere. As a result, the $\mathrm{SiC}$ ceramics with honeycomb structure and macroporous walls were prepared.

The bulk density of the sintered samples was measured through the conventional water-displacement method. The three-point bending strength of the sintered samples was performed by electronic universal test machine (CMT5205) with a span of 30 $\mathrm{mm}$ and cross-head speed of $0.5 \mathrm{~mm} / \mathrm{min}$. The dimension of testing samples is $3 \mathrm{~mm} \times 4 \mathrm{~mm} \times$ $36 \mathrm{~mm}$, and the testing number of each batch sample is 10. The phase compositions were analyzed by the X-ray diffractomer (XRD, Rigaku D/max-RA). The fracture morphologies of the honeycomb walls were observed by scanning electron microscope (SEM, HITACH S-4800). The pore structure characteristics of macropores in the honeycomb walls were evaluated by mercury porosimetry (Poremaster 60-GT, Quantachrome Instruments, USA).

\section{Results and discussion}

\subsection{Overview of honeycomb ceramics}

Extrusion molding The additive agents, such as binders, lubricants, plasticizer, dispersing agents and solvents, are crucial for the extrusion molding of $\mathrm{SiC}$ honeycomb ceramics. We choose $5 \mathrm{wt} \%$ HPMC and $3 \mathrm{wt} \%$ PVA as binders, $5 \mathrm{wt} \%$ oleic acid as lubricant, $3 \mathrm{wt} \%$ glycerol as plasticizer, and $2 \mathrm{wt} \%$ polyethylene glycol and $21 \mathrm{wt} \%$ water as solvents. As a result, a smooth flat green body with honeycomb structure and parallel channels can be obtained after the extrusion molding. The green body is dried at $120{ }^{\circ} \mathrm{C}$ for $24 \mathrm{~h}$ to remove the water in the body absolutely.

Sintering The sintering is a vital procedure for the honeycomb ceramics, and the sintering conditions such as temperature, time, atmosphere and heating rate will determine the microstructure and properties of the honeycomb ceramics. We adopt various heating rates in the sintering stage, that is, a slow heating rate of $5{ }^{\circ} \mathrm{C} / \mathrm{min}$ from room temperature to $600{ }^{\circ} \mathrm{C}$, followed by a heating rate of $10{ }^{\circ} \mathrm{C} / \mathrm{min}$ from $600{ }^{\circ} \mathrm{C}$ to $1000{ }^{\circ} \mathrm{C}$ which can remove the additive agents absolutely. When the heating temperature is in the range of $1000-1800{ }^{\circ} \mathrm{C}$, a rapid heating rate of $50{ }^{\circ} \mathrm{C} / \mathrm{min}$ is performed, and then the heating rate changes to $30{ }^{\circ} \mathrm{C} / \mathrm{min}$ in the temperature range of $1800-2160{ }^{\circ} \mathrm{C}$. The sintering time is $1 \mathrm{~h}$ at the sintering temperature of $2160{ }^{\circ} \mathrm{C}$, and the sintering atmosphere is Ar during the whole sintering stage.

Figure 1 shows the honeycomb channels and macroporous walls of a $\mathrm{SiC}$ honeycomb ceramic after sintering. The resultant $\mathrm{SiC}$ ceramics have a honeycomb structure with cell channels and macroporous channel walls, although there is little
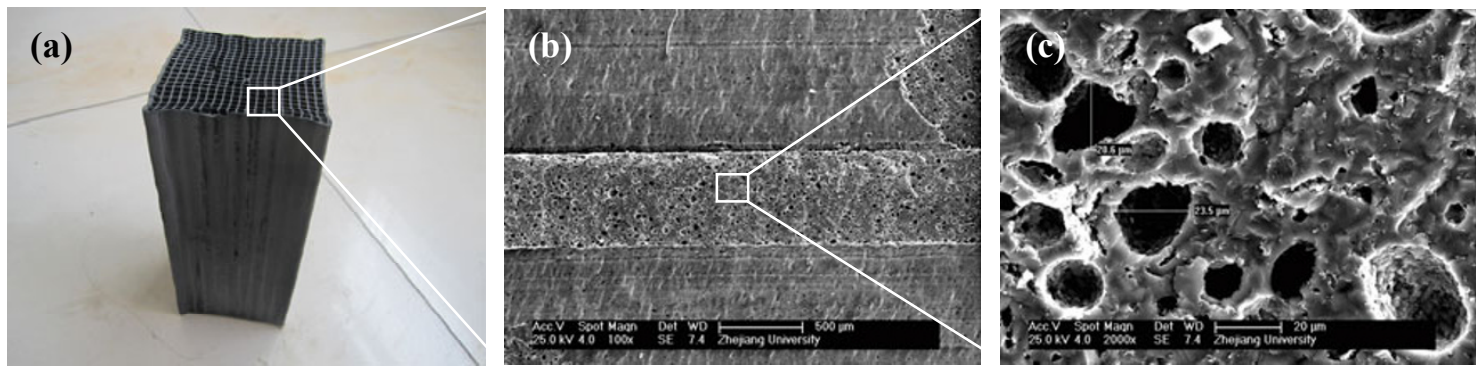

Fig. 1 (a) Honeycomb channels and (b,c) macroporous walls of sintered SiC ceramics. 
deformation or shrinkage in the channel walls. A square cell channel shaped in 70 cells per square inch monolith is obtained with a wall thickness of about $400 \mu \mathrm{m}$. The amount, size and shape of cell channels are related to the extrusion molds, while the pore structures such as porosity, pore size and pore volume of the channel walls are somewhat different and depend on the pore formation process.

\section{2 Sintering and mechanical properties}

Figure 2 shows the sintering behaviors of $\mathrm{SiC}$ honeycomb ceramics containing different starch contents. With the increase of starch content, the shrinkage ratio of honeycomb sintered body decreases and the mass loss increases, while the density decreases obviously. High mass loss indicates high volatilization of the additive agents and the pore-forming agent. When the starch content increases from $12.5 \mathrm{wt} \%$ to $20 \mathrm{wt} \%$, the bulk density of $\mathrm{SiC}$ honeycomb ceramics decreases from $2.42 \mathrm{~g} / \mathrm{cm}^{3}$ to $2.20 \mathrm{~g} / \mathrm{cm}^{3}$. The removal of starch will result in a lot of macropores on the walls, which inevitably deteriorate the density of channel walls.
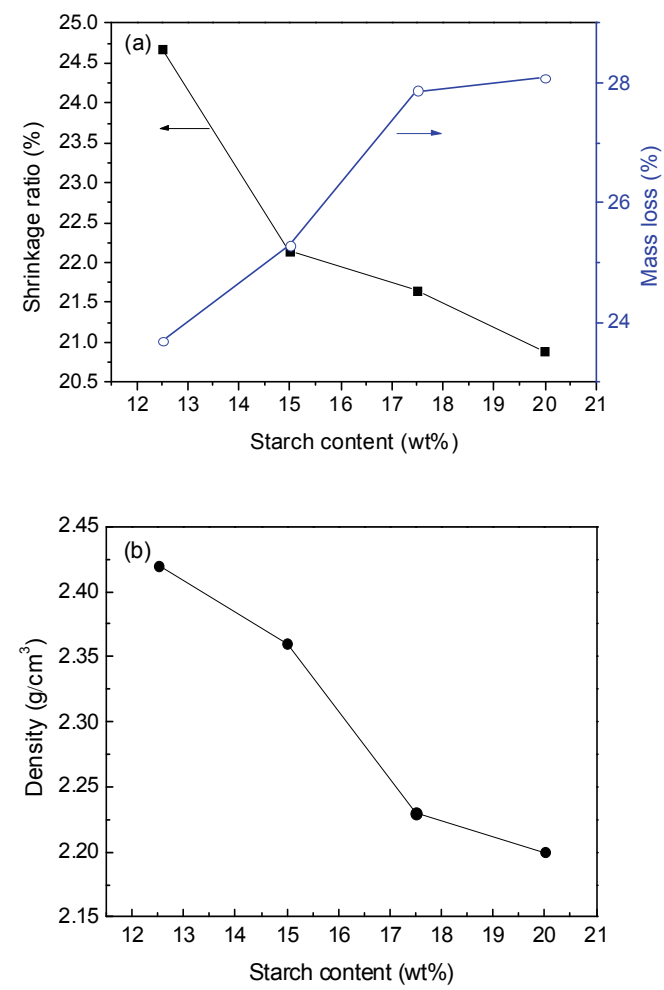

Fig. 2 (a) Shrinkage ratio and (b) density of $\mathrm{SiC}$ honeycomb ceramics containing different starch contents.
Figure 3 shows the bending strength of $\mathrm{SiC}$ honeycomb ceramics containing different starch contents. The bending strength of $\mathrm{SiC}$ honeycomb ceramics obviously decreases with the increase of starch content. The increase in starch content will result in the increase of macropore amount in channel walls, which inevitably deteriorates the mechanical property of $\mathrm{SiC}$ honeycomb ceramics. From the load-deformation curve of the honeycomb ceramic with $15 \mathrm{wt} \%$ starch, it is seen that the curve shows a slow upward trend with the increase of load, and a relative large peak occurs and keeps for some time when the load reaches a certain level, and then rapidly declines with the further increase of starch content. It indicates that the deformation of honeycomb ceramics is relative slow with the load, which is attributed to the elasticity of honeycomb structure. When the load reaches to a high level, the honeycomb structures will be broken or damaged, resulting in the decline of curve.

\section{3 Phase compositions and microstructure}

Figure 4 shows the XRD patterns of $\mathrm{SiC}$ honeycomb ceramics containing different starch contents. The main crystalline phases include $6 \mathrm{H}-\mathrm{SiC}, 4 \mathrm{H}-\mathrm{SiC}$ and $2 \mathrm{H}-\mathrm{SiC}$, resulting from the $\mathrm{SiC}$ composite powders.
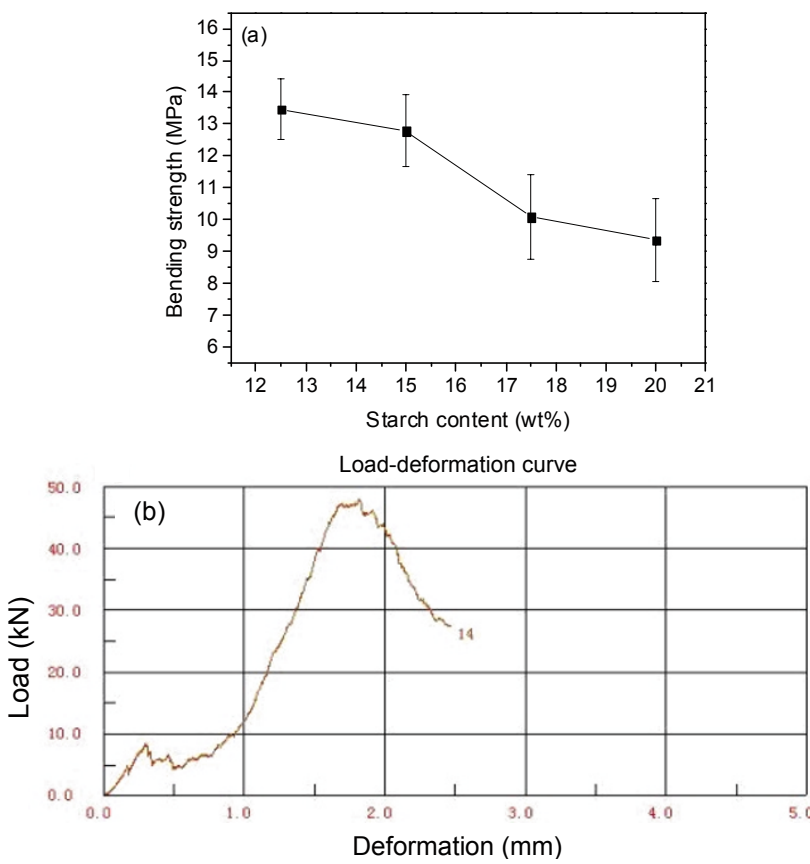

Fig. 3 (a) Bending strength of $\mathrm{SiC}$ honeycomb ceramics containing different starch contents and (b) load-deformation curve of $\mathrm{SiC}$ honeycomb ceramic with $15 \mathrm{wt} \%$ starch. 


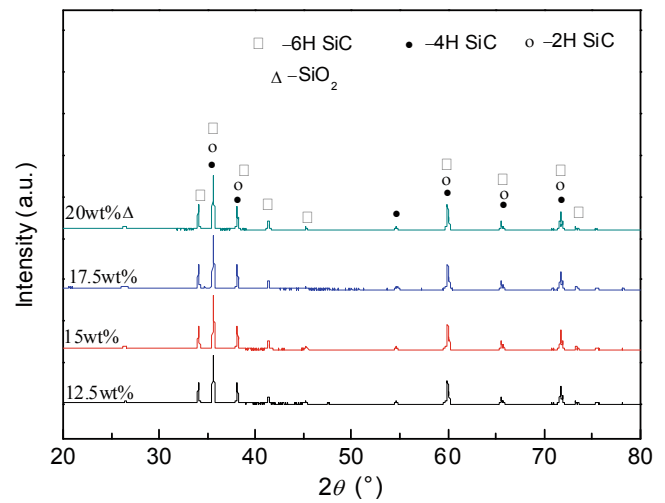

Fig. 4 XRD patterns of $\mathrm{SiC}$ honeycomb ceramics containing different starch contents.

The main crystalline phases do not vary with the variation of starch content obviously. It indicates that the pore-forming agent has no effect on the phase compositions of $\mathrm{SiC}$ honeycomb ceramics.

Figure 5 shows the SEM images of surface of channel walls at different starch contents. The micrographs provide evidence of open macropores on the channel walls regardless of the starch content. The macropores of the sample are spherical with the size of $10-30 \mu \mathrm{m}$ at $12.5 \mathrm{wt} \%$ of starch. When the starch content increases to $20 \mathrm{wt} \%$ and above, the macropore amount increases obviously, and becomes interconnected, while the pore size changes a little with the starch content. These results suggest that the pore structure can be adjusted to some extent by controlling the addition of starch.

\section{4 Pore structures}

Figure 6 shows the pore size distributions determined by mercury porosimetry for the channel walls at different starch contents $(15 \mathrm{wt} \%, 17.5 \mathrm{wt} \%$ and $20 \mathrm{wt} \%)$. The cumulative pore volume is relatively low and the pore size distribution is a little wide and flat at $15 \mathrm{wt} \%$ of starch, which do not change much at $17.5 \mathrm{wt} \%$. It indicates that most of created macropores in the two samples are still closed or isolated, although the two samples seem to have a lot of open macropores as shown in Fig. 5. When the starch content increases to $20 \mathrm{wt} \%$, the sample possesses a sharp pore size distribution, and the pores are distributed roughly between $0.08 \mu \mathrm{m}$ to $0.4 \mu \mathrm{m}$, which is much lower than the pore size $(10-40 \mu \mathrm{m})$ of $\mathrm{RSiC}$ honeycomb walls. It indicates that some small interconnected pores with a regular shape distribute on the large isolated macroporous interiors.

Figure 7 shows the median pore size and porosity of channel walls at different starch contents $(15 \mathrm{wt} \%$, $17.5 \mathrm{wt} \%$ and $20 \mathrm{wt} \%$ ). The median pore size and porosity of the samples increase with an increase starch content. The median pore size and porosity increase from $105 \mathrm{~nm}$ and $19.8 \%$ to $220 \mathrm{~nm}$ and $37 \%$ respectively, when the starch content increases from
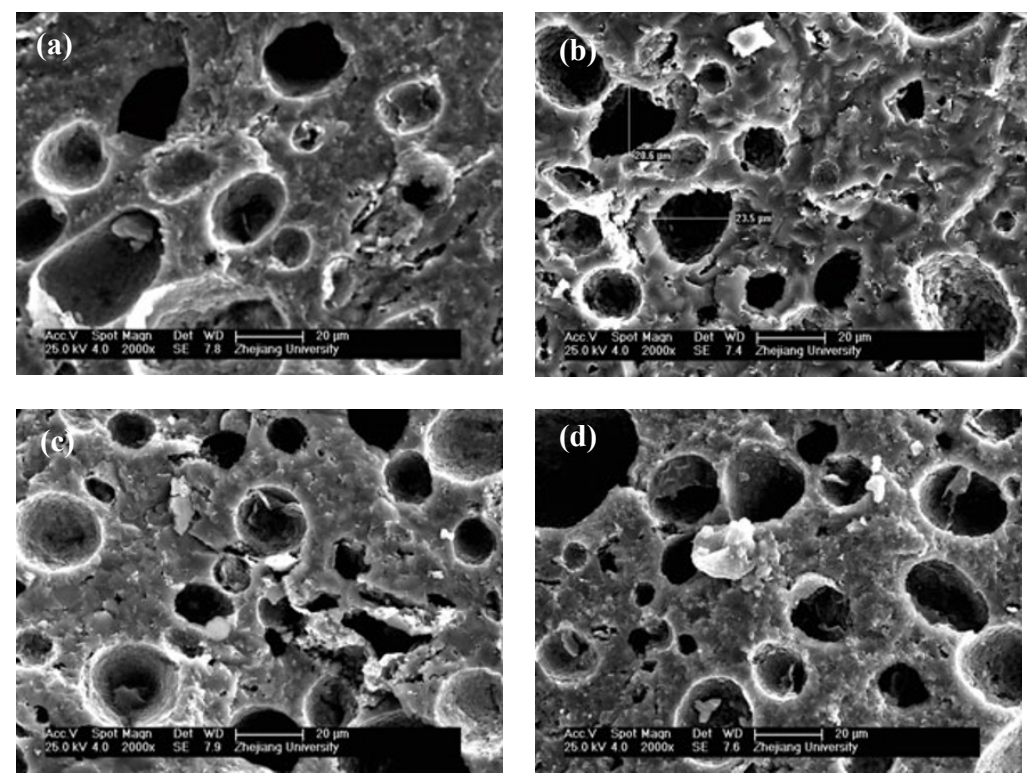

Fig. 5 SEM images of surface of channel walls at different starch contents: (a) $12.5 \mathrm{wt} \%$, (b) $15 \mathrm{wt} \%$, (c) 17.5 $\mathrm{wt} \%$, (d) $20 \mathrm{wt} \%$. 


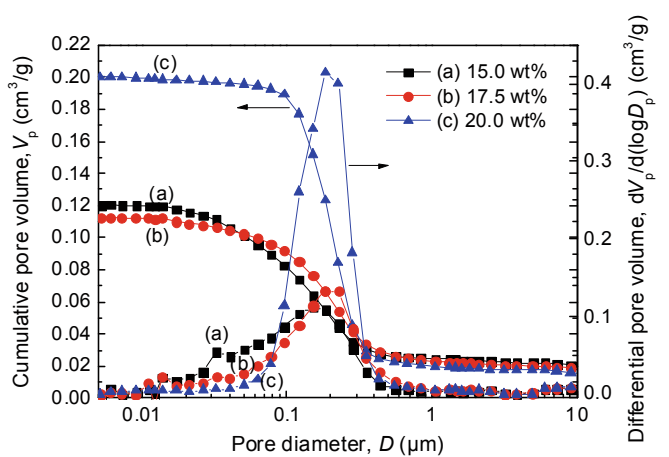

Fig. 6 Pore size distributions determined by mercury porosimetry for the channel walls at different starch contents: (a) $15 \mathrm{wt} \%$, (b) $17.5 \mathrm{wt} \%$, (c) $20 \mathrm{wt} \%$.
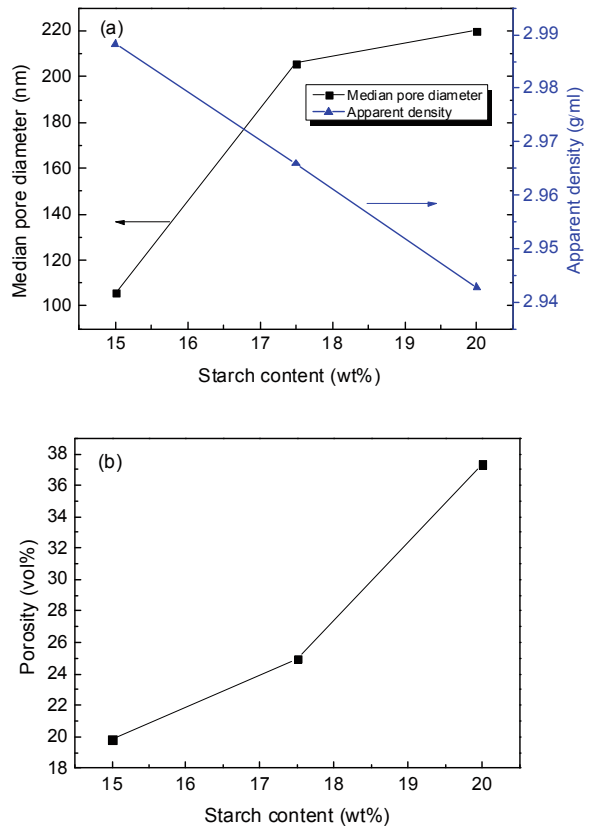

Fig. 7 (a) Median pore size and (b) porosity of channel walls for $\mathrm{SiC}$ honeycomb ceramics containing different starch contents.

$15 \mathrm{wt} \%$ to $20 \mathrm{wt} \%$. The increase in porosity and pore size with increasing starch content is attributed to the increased mass loss of the specimens as shown in Fig. 1 and the removal of pore-forming agent.

\section{Conclusions}

$\mathrm{SiC}$ honeycomb ceramics with macroporous walls were prepared by pressureless sintering technology. The extrusion molding constructed the honeycomb structure with 70 cells per square inch and a wall thickness of about $400 \mu \mathrm{m}$, while the starch as pore-forming agent formed spherical macropores with a size of $10-30 \mu \mathrm{m}$ on the walls. The pore formation of starch on the channel walls weakened the bulk density and bending strength of honeycomb ceramics, while did not change the phase compositions. The $\mathrm{SiC}$ honeycomb ceramic containing $20 \mathrm{wt} \%$ starch had a macrostructure consisting of large spherical macrospores and small interconnected pores in interiors, with a porosity of $37 \%$. The honeycomb ceramics with macroporous walls are promising for wide applications such as filtration, separation, catalysis and so on.

\section{Acknowledgements}

This work is supported by the Innovation Fund for Technology-based Firms of China (12C26113303061) and High Science \& Technique Brainstorm Project of Zhejiang Province of China (No. 2012C01032-1).

Open Access: This article is distributed under the terms of the Creative Commons Attribution License which permits any use, distribution, and reproduction in any medium, provided the original author(s) and the source are credited.

\section{References}

[1] Eom J-H, Kim Y-W, Raju S. Processing and properties of macroporous silicon carbide ceramics: A review. J Asian Ceram Soc 2013, 1: 220-242.

[2] Galsterer D, Travitzky N, Wolff T, et al. Microstructure and properties of $\mathrm{SiC}$ honeycomb structures. Adv Eng Mater 2008, 10: 1134-1140.

[3] Ohzawa Y, Nakane K, Gupta V, et al. Preparation of SiC-based cellular substrate by pressure-pulsed chemical vapor infiltration into honeycomb-shaped paper preforms. J Mater Sci 2002, 37: 2413-2419.

[4] Bhattacharya AK, Heinrich JG. Cellular SiC ceramic from stems of corn-Processing and microstructure. J Mater Sci 2006, 41: 2443-2448.

[5] Qian J-M, Jin Z-H, Wang X-W. Porous SiC ceramics fabricated by reactive infiltration of gaseous silicon into charcoal. Ceram Int 2004, 30: 947-951.

[6] Dey A, Kayal N, Chakrabarti O. Preparation of porous $\mathrm{SiC}$ ceramics by an infiltration technique. Ceram Int 2011, 37: 223-230. 
[7] Jang B-K, Sakka Y. Thermophysical properties of porous $\mathrm{SiC}$ ceramics fabricated by pressureless sintering. Sci Technol Adv Mater 2007, 8: 655-659.

[8] Agrafiotis CC, Mavroidis I, Konstandopoulos AG, et al. Evaluation of porous silicon carbide monolithic honeycombs as volumetric receivers/ collectors of concentrated solar radiation. Sol Energ Mat Sol C 2007, 91: 474-488.
[9] Bai J, Yang X, Shi Y, et al. Fabrication of directional $\mathrm{SiC}$ porous ceramics using $\mathrm{Fe}_{2} \mathrm{O}_{3}$ as pore-forming agent. Mater Lett 2012, 78: 192-194.

[10] Guo X, Cai X, Zhu L, et al. Preparation and pore structure characteristics of SiC honeycomb ceramics with macroporous walls. Ceram Int 2014, 40: 6339-6343. 